Gordon J. Alexander, University of Minnesota;

Alexandre M. Baptista, The George Washington University;

Shu Yan, University of South Carolina, USA

\title{
BANK REGULATION AND STABILITY: AN EXAMINATION OF THE BASEL MARKET RISK FRAMEWORK
}

In attempting to promote bank stability, the Basel Committee on Banking Supervision (2006) provides a framework that seeks to control the amount of tail risk that large banks take in their trading books. However, banks around the world suffered sizeable trading losses during the recent crisis. Due to the size and prevalence of losses, a formal examination of whether the Basel framework allowed banks to take substantive tail risk in their trading books without a capital requirement penalty is of particular interest. In this paper, we provide such an examination and show that the Basel framework indeed allowed banks to do so. Hence, our paper supports the view that the Basel framework leaves room for considerable improvements regarding the treatment of tail risk.

Alexander, G.J. Bank regulation and stability: an examination of the basel market risk framework [Text] / G.J. Alexander, A.M. Baptista, Y. Shu // Міжнародна банківська конкуренція: теорія і практика: збірник тез доповідей VII Міжнародної науково-практичної конференції (24-25 травня 2012 р., м. Суми): у 2-х т. - Суми: УАБС НБУ, 2012. - Т. 1. - С. 18-19. 